\title{
KEPEMIMPINAN KEPALA SEKOLAH DALAM MENINGKATKAN JUMLAH SISWA DI SMP MUHAMMADIYAH AL MUJAHIDIN GUNUNGKIDUL
}

\author{
Ari Nopriyani dan Enung Hasanah \\ Universitas Ahmad Dahlan (UAD), Yogyakarta, Indonesia \\ Email: farahppkn@gmail.com dan enung.hasanah@mp.uad.ac.id.
}

\begin{abstract}
This study aims to explore the principal's leadership in increasing the number of students at SMP Muhammadiyah Al Mujahidin Gunungkidul, Yogyakarta Special Region. The research was conducted at SMP Muhammadiyah Al Mujahidin Gunungkidul. We use qualitative research with a case study method. The process of collecting data by observation, interviews, and documentation. The data checking technique used source triangulation, technique triangulation, and time triangulation. Data analysis in the form of data reduction, data display and data verification. From the research results it is known that SMP Muhammadiyah AL Mujahidin in building community trust cannot be separated from the leadership role of the principal who has several strategies as follows: 1) conveying a clear vision and mission, 2) encouraging teachers to improve their professional analysis, 3) creating a conducive environment, 4) student-friendly learning, 5) building strong management, 6) creating a broad but balanced curriculum, 7) assessing and reporting meaningful student achievement, and 8) involving parents and the community.
\end{abstract}

Keywords: leadership; principal; strategy; ppdb

\section{Abstrak}

Penelitian ini bertujuan untuk mengeksplorasi kepemimpinan kepala sekolah dalam meningkatkan jumlah siswa di SMP Muhammadiyah Al Mujahidin Gunungkidul, Daerah Istimewa Yogyakarta. Penelitian dilaksanakan di SMP Muhammadiyah Al Mujahidin Gunungkidul. Penelitian ini menggunakan kualitatif dengan metode studi kasus. Proses pengambilan data dengan observasi, wawanacara, dan dokumentasi. Teknik Pemeriksaan data mengunakan triangulasi sumber, triangulasi teknik, dan triangulasi waktu. Analisis data berupa Reduksi data, display data dan verifikasi data. Dari hasil penelitian diketahui bahwa SMP Muhammadiyah Al Mujahidin dalam membangun kepercayaan masyarakat tidak lepas dari peran kepemimpinan kepala sekolah yang memiliki beberapa strategi sebagai berikut : 1) penyampaian visi dan misi yang jelas, 2) mendorong guru untuk meningkatkan profesioanalismenya, 3) menciptakan lingkungan yang kondusif, 4) pembelajaran yang ramah siswa, 5) membangun manajemen yang kuat, 6) menciptakan kurikulum yang luas tapi seimbang, 7) penilaian dan pelaporan prestasi siswa yang bermakna, serta 8) pelibatan orang tua dan masyarakat. 
Kata kunci: kepemimpinan; kepala sekolah; strategi; PPDB

Coresponden Author

Email: farahppkn@gmail.com

Artikel dengan akses terbuka dibawah lisensi

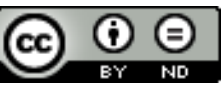

\section{Pendahuluan}

Pendidikan merupakan proses untuk membantu peserta didik agar mampu tumbuh menjadi dirinya sendiri, yang tumbuh sejalan dengan bakat, watak, kemampuan, dan hati nuraninya secara utuh. Pendidikan tidak dimaksudkan untuk mencetak karakter dan kemampuan peserta didik sama seperti gurunya (Mulyasana, 2011), melainkan sebagai proses pembangunan karakter yang didasari nilai-nilai moral (E. Hasanah, 2019), agar mampu mencapai identitas diri yang positif (Hasanah, et al, 2019). Oleh karena itu, pendidikan perlu dikemas menjadi sebuah proses yang komprehensif, yang mampu membangun afektif, kognitif, maupun psikomotorik peserta didik, dalam upaya membantu generasi muda untuk tumbuh menjadi manusia seutuhnya, yang bermoral, memiliki pengetahuan yang luas, serta terampil dalam melakukan berbagai pekerjaan, agar dapat memenuhi harapan masyarakat.

Sekolah sebagai penyelenggara pendidikan (Hammer, 2016), harus memiliki kemampuan untuk meningkatkan sinergi antara potensi anak, dukungan orang tua, dan sekolah (Ainscow et al., 2006), agar dapat menghasilkan output pendidikan yang berkualitas. Mutu lulusan yang baik, dapat menjadi salah satu aspek yang menarik minat dan kepercayaan sekolah (Ferlie et al., 2010). Selain itu, sekolah perlu meningkatkan kemampuan komunikasi publik agar sekolah lebih dikenal oleh masyarakat (Wiyono et al., 2019). Semua itu dapat berjalan dengan baik jika sekolah digerakkan oleh seorang pimpinan yang memiliki kapasitas untuk memimpin sekolah. Terlebih dalam masa pandemi covid-19, seorang kepala sekolah harus semakin kreatif dalam membangun mutu sekolah (Citra Resmi \& Hasanah, 2020; Hasim \& Hasanah, 2020), untuk dapat menarik minat masyarakat.

Peran kepala sekolah sebagai pemimpin di satuan pendidikan yang ada dituntut untuk melakukan berbagai inovasi dengan berbagai penyesuaian sesuai dengan kebutuhan yang ada dan segala perencanaan yang matang. Pengendalian keadaan seperti saat pandemi covid 19 ini harus dilakukan kepala sekolah agar pelayanan pendidikan tetap berjalan dengan baik dengan menjunjung tinggi keselamatan dan Kesehatan warga sekolah (Amini \& Ginting, 2020).

Ciri-ciri pemimpin yang baik adalah sehat, cerdas, setia, jujur, berpendidikan dan berpengalaman (Caldwell, 2015). Kepemimpinan yang berkualitas adalah kepemimpinan yang selalu berusaha untuk menunjukkan lembaga pendidikan dan meningkatkan mutu lulusan yang dikeluarkan (Ekosiswoyo, 2016). Oleh karena itu strategi kepala sekolah dalam merekrut siswa baru sangat diperlukan untuk melanjutkan program-program yang telah ditetapkan akan dapat dilaksanakan dengan baik sesuai 
yang diinginkan. Kepemiminan sebagai suatu kemampuan seseorang (pemimpin) untuk mempengaruhi, memotivasi, dan memungkinkan orang lain untuk berkontribusi terhadap efektifitas dan keberhasilan organisasi (Fatah, 2004)). Pemimpin yang baik dapat menjadi faktor utama untuk keberhasilan sekolah dalam menarik minat masyarakat, sehingga sekolah tidak akan mengalami kesulitan dalam proses penerimaan peserta didik baru (PPDB) (Purwanti et al., 2018).

Penerimaan peserta didik pada hakikatnya proses pencarian, menyeleksi, dan menentukan siswa yang nantinya akan menjadi peserta didik di lembaga sekolah yang bersangkutan. Dalam Pelaksanaan Penerimaan Peserta Didik Baru (PPDB) ini, biasanya setiap sekolah melakukan pembentukan panitia penerimaan peserta didik baru yang melibatkan semua unsur guru, pegawai TU (Tata Usaha), dewan sekolah/komite sekolah, selain itu sekolah juga melakukan sosialisasi ke sekolah-sekolah yang menjadi target PPDB, membuat dan memasang pengumuman penerimaan siswa baru yang dilakukan secara terbuka sehingga masyarakat mendapatkan informasi yang jelas dan komprehensif tentang penerimaan siswa baru. Semua yang dilakuakn oleh pihak sekolah dalam PPDB ditujukan untuk menarik minat masyarakat (Ferlie et al., 2010). Meskipun pola PPDB di setiap sekolah hampir sama, tetapi minat hasil PPDB setiap sekolah berbeda-beda dari tahun ke tahun, tergantung dari keberhasilan manajemen sekolah dalam mebangun mutu sekolah dan mempromosikannya kepada masyarakat (Nawaz Khan \& Qureshi, 2010).

Proses PPDB dilakukan oleh sekolah dengan strategi dan caranya masing-masing, dari beberapa hasil penelitian tersebut adalah penelitian Joni Nur Junaidi yang berjudul Strategi Kepala Sekolah dalam Rekrutmen Penerimaan Peserta Didik Baru Di Sekolah Menengah Atas Negeri 5 Merangi, bahwa strategi kepala sekolah dalam rekrutmen siswa di Sekolah Menengah Atas Negeri 5 Merangin adalah: Kepala sekolah melibatkan semua guru dan SDM lembaga sekolah serta masyarakat untuk melaksanakan kegiatan strategi rekrutmen yang akan dilakukan. Strategi dilakukan melalui perencanaan pembentukan tim penerimaan peserta didik baru. Setelah terbentuknya tim atau panitia PPDB kepala sekolah bersama panitia PPDB melakukan rapat musyawarah panitia, dan hingga pelaksanaan rekrutmen. Sebelum dibentuknya panitia PPDB pihak sekolah lebih awal melakukan berbagai persiapan dan pendekatan terhadap masyarakat untuk untuk melancarkan strategi rekrutmen, menjelang jadwal rekrutmen dilaksanakan. Pengumpulan data dan berkas sebagai media dan bahan rekrutmen disiapkan. Strategi intern dengan menata lingkungan sekolah, memperbaik sarana dan gedung-gedung yang rusak juga dilakukanoleh pihak sekolah. Penyusunan dan penataan ruangan mulai dirapikan kembali sehingga menampakkan estetika yang baik. Strategi ekstern yang dilakukan oleh kepala sekolah SMAN 5 Merangin adalah dengan memasang spanduk PPDB dijalan, mengirim brosur ke sekolah SMP, MTs/sederajat, penggunakan rekrutmen melalui media online website sekolah, kunjungan ke sekolah-sekolah untuk melakukan sosialisasi kepada calon peserta didik baru serta koordinasi bersama pihak terkait, seperti komite dan para kepala sekolah (Junaidi, 2019). 
Dalam penelitian tersebut sama-sama melakukan beberapa strategi dalam upaya untuk meningkatkan jumlah peserta didik baru, awal proses kegiatan PPDB dilakukan dengan melakukan beberapa tahapan yang semua dilakukan dalam rangka agar mendapat pengakuan dari masyarakat termasuk didalamnya dengan meningkatkan sarana dan prasarana sekolah agar siswa mendapatkan fasilitas yang baik ketika bersekolah di sekolah tersebut.

Hasil tersebut diatas juga untuk mempertegas penelitian Marsiti yang berjudul Strategi Kepala Sekolah dalam Implementasi Sistem Manajemen Mutu ISO 9001:2000 untuk penerimaan siswa baru ( Studi Multi Kasus pada SMA Islam Kepanjen Malang dan SMPK Santa Maria II Malang).Strategi kepala sekolah dalam perencanaan penerimaan siswa baru untuk meningkatkan layanan siswa meliputi: (1) melakukan sosialisasi terhadap semua civitas di lembaga untuk perbaikan sistem, (2) proses penerimaan siswa baru dilaksanakan sebelum dimulainya tahun ajaran baru, (3) strategi yang di tetapkan tidak terbatas pada salah satu aspek melainkan pada semua aspek baik itu sarana prasarana, tenaga pendidik, kurikulum dan pembiayaan sekolah, dan (4) penekanan pada pemberian layanan pada siswa.Strategi kepala sekolah dalam implementasi penerimaan siswa baru untuk meningkatkan layanan siswa meliputi: (1) perbaikan pada sistem penerimaan siswa baru berdasarkan pagu, (2) tes IQ dilaksanakan untuk melihat kemempuan siswa dalam proses pendampingan pembelajaran yang akan dilaksanakan, terutama pelajaran IPA (3) Pengendalian dokumen penerimaan siswa baru. Evaluasi pelaksanaan penerimaan siswa baru dalam meningkatkan layanan siswa meliputi: (1) pelaksanaan audit internal secara berkala guna menentukan apakah sistem manajemen mutu yang telah ditetapkan memenuhi aturan yang direncanakan terhadap persyaratan standar internasional ISO 9001:2000, (2) meningkatkan kinerja dilembaga pendidikan terutama terhadap layanan siswa yang prima disekolah, dan (3) melakukan pengukuran dengan standar yang telah ditentukan, sehingga diketahui selisih antara hasil pengukuran dengan standar yang telah ditentukan (Marsiti, 2011).

Diperkuat dari penelitian dari Ulfatul Shafira yang berjudul Strategi Kepala Sekolah Dasar dalam Rekrutmen siswa baru di SDN 20 Banda Aceh, perencanaan strategi kepala sekolah dalam rekrutmen siswa baru, meliputi (1) rekrutmen peserta didik dilaksanakan secara online; (2) seleksi peserta didik dilakukan dengan melihat domisili dan umur dari siwa baru; (3) penetapan siswa baru; (4) melaksanakan orientasi untuk siswa baru; (5) pencatatan dan pelaporan siswa baru. Kedua, proses rekrutmen siswa baru, meliputi (1) membentuk panitia rekrutmen siswa baru; (2) pihak sekolah memberikan informasi mengenai rekrutmen siswa baru dengan memasangkan baliho besar; (3) pendaftaran siswa baru dilakukan secara online; (4) penyeleksian; (5) pengumuman siswa baru; (6) rapat penentuan siswa baru; (7) melakukan registrasi (Shafira, 2019).Hasil penelitian Reza Taruna dalam Tesis yang berjudul Pengelolaan Rekrutmen Peserta Didik dalam Peningkatan Animo Masyarakat di SMAN 16 Banda Aceh, bahwa 1) Pengelolaan kegiatan rekrutmen peserta didik di SMAN 16 Banda Aceh sudah dijalankan sesuai dengan apa yang direncanakan yang mana sekolah membuat rapat untuk membentuk panitia PPDB selanjutnya sekolah mengadakan sosialisaisi 
terhadap masyarkat dan membagikan brosur serta memasang spanduk disimpang jalan menuju kesekolah.2) Pelaksanaan kegiatan rekrutmen peserta didik dalam peningkatan animo masyarakat sekolah membuat rapat untuk PPDB, rapat penentuan peserta didik, pembuatan pengumuman, pendaftaran peserta didik, seleksi peserta didik, penentuan peserta didik yang diterima, dan pendaftaran ulang (Taruna, 2020).

Beberapa penelitian diatas merupakan penelitian yang senada mengenai strategi kepala sekolah dalam meningkatkan jumlah siswa dalam kegiatan PPDB. Namun belum ada penelitian yang membahas Best Prectices Kepemimpinan Kepala Sekolah dalam meningkatkan jumlah siswa di SMP Muhammadiyah Al Mujahidin Logandeng Gunungkidul. Kepala sekolah memegang peranan penting dalam menentukan maju mundurnya sekolah, dalam hal PPDB seorang kepala sekolah harus mempunyai strategi yang jitu untuk menarik siswa sebanyak-banyak, dan ini dibuktikan oleh Kepala Sekolah SMP Muhammdiyah Al Mujahidin bahwa kepercayaan masyarakat terhadap sekolah tersebut melalui peningkatan jumlah siswa setiap tahunnya,serta peningkatan kualiatas dan mutu sekolah tersebut. Selain itu juga karena kepemimpinan (Thoha, 2016) kepala sekolah tersebut dalam mengendalikan seluruh stekholder dalam melaksanakan program sekolah, termasuk program kegaiatan PPDB ini.

SMP Muhammadiyah Al Mujahidin, Gunung Kidul, Yogyakarta, merupakan salah satu sekolah Muhammadiyah di Gunung Kidul yang mengalami peningkatan, baik jumlah peminatnya maupun jumlah prestasi yang diraih oleh para siswanya. Proses PPDB tahun pertama SMP Al Mujahidin melakukan sosialisasi dan publikasi untuk melakukan rekruitmen siswa melalui kegiatan PPDB (Penerimaan Peserta Didik Baru) yang dibuka sejak tanggal 13-27 Mei 2013. Pada saat itu jumlah siswa yang diterima berjumlah 60 siswa dan setelah melalui proses seleksi diterima 48 siswa atau 2 kelas. Dalam perkembangan selanjutnya dari 48 siswa yang mendaftar hanya 45 siswa yang melakukan herregistrasi dan dari 45 siswa tersebut terdapat 3 siswa lagi yang mengundurkan diri karena diterima di Mualimat dan 1 orang lagi pindah ke sebuah Pondok Pesantren di Magelang. Dengan demikian jumlah siswa SMP Al Mujahidin saat itu tinggal 42. Di sisi lain masih ada juga beberapa pendaftar yang menyusul, oleh karena itu sekolah dan panitia pendiri kemudian mempertimbangkan untuk melakukan seleksi terhadap pendaftar susulan dan dari 4 pendaftar susulan tersebut setelah diuji 2 pendaftar diterima sehingga jumlah siswa berjumlah 44. Hal ini dilakukan karena kuota yang diberikan oleh Dinas Pendidikan untuk SMP Al Mujahidin adalah 2 kelas.

Dalam perjalanan berikutnya ternyata terdapat beberapa siswa yang menghendaki pindah ke SMP Al Mujahidin namun tidak semuanya bisa diterima. Hal ini dikarenakan SMP Muhammadiyah Al Mujahidin sudah menetapkan kualifikasi siswa yang akan diterima yaitu minimal mendapatkan NEM 24. Dari beberapa siswa yang menghendaki pindah tersebut akhirnya ada 1 siswa yang bisa diterima dengan alasan secara kualifikasi NEM memenuhi dan bersedia mengikuti ketentuan dan persyaratan yang ditentukan oleh sekolah. Dengan demikian pada tahun pelajaran 2013/2014 siswa SMP Muhammadiyah Al Mujahidin berjumlah 45 siswa dengan jumlah siswa laki-laki 23 siswa dan 22 siswa perempuan. 
Dari tahun ke tahun SMP Muhammadiyah Al Mujahin menunjukan progres capaian siswa siswi yang sangat luar biasa ini membuktikan bahwa sekolah tersebut mempunyai keunggulan yang tidak di miliki sekolah lain, serta peran kepemimpinan Kepala sekolah dalam meningkatkan jumlah siswanya, melalui pengambilan kebijakan untuk melaksanakan rekrutmen Penerimaan Peserta Didik Baru, serta memiliki pegangan cara yang komprehensif dan intergartif. Progres pencapaian siswa dari tahun ke tahun bisa dilihat pada gambar 1 di bawah ini:

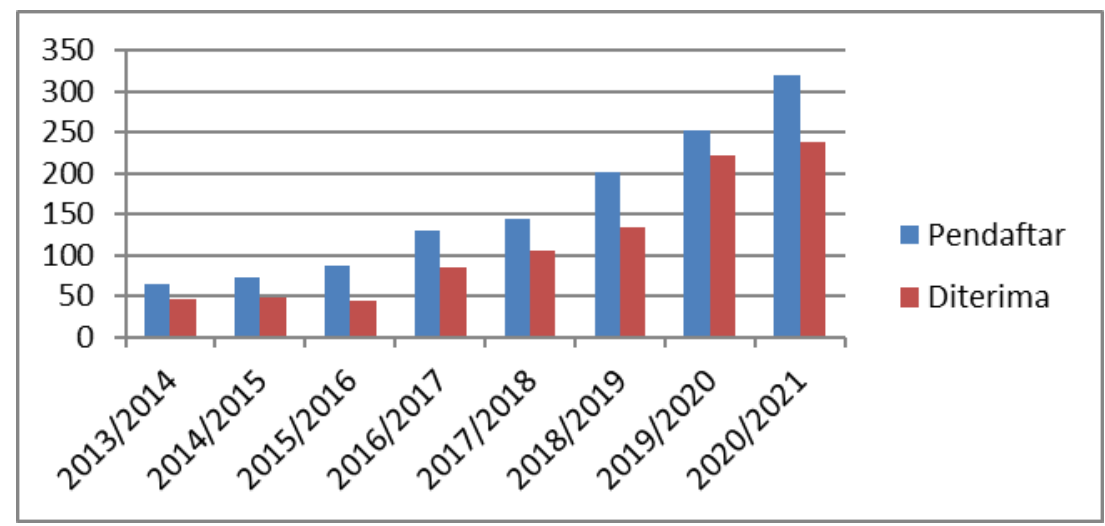

Gambar 1

Grafik Jumlah Kenaikan Jumlah Siswa Setiap Tahun

Berdasarkan hasil kesuksesan kepala sekolah SMP Muhammadiyah Al Mujahidin dalam meningkatkan jumlah siswa dari tahun ketahun maka penelitian tentang Best Practice Kepala Sekolah SMP Al Mujahidin dalam meningkatkan jumlah siswa dari tahun ke tahun, diharapkan dapat dijadikan contoh bagi sekolah lain dengan kondisi yang sama untuk dikembangkan dan dimanfaatkan hasilnya bagi kemajuan sekolah dalam meningkatkan jumlah siswa.

\section{Metode Penelitian}

Penelitian ini mengunakan penelitian kualitatif dengan metode studi kasus (Patton, 2012). Berdasarkan fokus masalah, tujuan, subjek penelitian dan karakteristik data, maka pendekatan penelitian yang dianggap tepat dalam penelitian ini adalah studi kasus. Pendekatan tersebut berdasar pada alasan bahwa peneliti bermaksud memperoleh data-data tentang. Kepemimpinan Kepala Sekolah dalam meningkatkan jumlah siswa di SMP Muhammadiyah Al Mujahidin Logandeng Gunungkidul. Sumber data penelitian ini adalah populasi dan sampel. Populasi adalah keseluruhan subjek penelitian (Arikunto, 2010). Populasi dalam penelitian ini adalah seluruh warga sekolah SMP Muhammdiyah Al Mujahidin sejumlah 36. Sampel adalah sebagian yang diambil dari keseluruhan objek yang diteliti dan dianggap mewakili seluruh populasi (Arikunto, 2010). Sampel dalam penelitian ini adalah kepala sekolah, guru, dan karyawan di SMP Muhammadiyah Al Mujahidin Logandeng Gunungkidul.

Secara lebih rinci, di bawah ini kami sajikan keseluruhan proses pemgambilan data yang kami lakukan sebagai berikut: 
a. Observasi digunakan untuk mencermati beragam fenomena seperti proses pelaksanaan penerimaan peserta didik baru sehingga jumlah siswa bisa naik setiap tahunnya, strategi yang dilakukan kepala sekolah untuk menarik siswa mulai dari tahap studi orientasi suasana lingkungan, implementasi sampai evaluasi hasil. Observasi yang dilakukan dalam penelitian ini bertujuan melihat fenomen-fenomena yang terkait Kepemimpinan Kepala Sekolah dalam meningkatkan jumlah siswa.

b. Wawancara yang digunakan dalam penelitian ini adalah wawancara terstruktur. Peneliti menggunakan pedoman wawancara agar tidak keluar dari focus yang telah ditentukan. Data yang dikumpulkan melalui wawancara bersifat uraian kata. Wawancara dilakukan kepada kepala sekolah dan guru, pelaksanaan wawancara dilakukan tiga puluh menit setiap orangnya.

c. Dokumentasi, kami gunakan untuk mendapatkan data dalam bentuk visualisasi yaitu berupa profil sekolah dokumen program kerja sekolah, dokumen pelaksanaan Penerimaan Peserta Didik Baru.

Untuk menjamin objektivitas terhadap proses dan interpretasi hasil penelitian, kami melakukan traiangulasi data (Moleong, 2018). Dalam konteks ini kami melakukan trainggulasi sumber, trianggulasi metode pengambilan data, dan trianggulasi waktu.

Aktivitas dalam analisis data kualitatif dilakukan secara interaktif dan berlangsung secara terus menerus sampai tuntas, sehingga datanya jenuh (Matthew, 1994). Proses analisis data yang kami lakukan terdiri dari reduksi data, penyajian/display data, dan penatikan kesimpulan/verifikasi.

\section{Hasil dan Pembahasan}

SMP Muhammadiyah Al-Mujahidin merupakan sekolah yang tergolong baru di Kabupaten Gunungkidul, berdiri pada tanggal 14 Juni 2013. Setelah melalui verifikasi dari Disdikpora Kabupaten Gunungkidul pada akhirnya Kepala Dinas Pendidikan Pemuda dan Olah Raga menerbitkan SK nomor 421/133/KPTS/2013 tentang Persetujuan Pembukaan SMP Swasta Tahun Pelajaran 2013/2014.

SMP Muhammadiyah Al Mujahidin adalah sekolah Islam unggul di Kabupaten Gunungkidul. Visi sekolah unggul, berbudi dan berprestasi, sekolah ini tampil menjadi sekolah unggulan dengan mengedepankan sense of quality, dengan misi Membimbing peserta didik untuk memahami ajaran Islam secara komprehensif; Membantu peserta didik menjadi pribadi yang mencintai ilmu pengetahuan dan teknologi; Membangun budaya sekolah yang membelajarkan dan mendorong semnagat keunggulan; Mengembangkan sistem dan manajemen sekolah yang berbasis penjamin mutu.

Dengan visi dan misi ini, SMP Muhammadiyah Al-Mujahidin mencoba membangun citra sekolah unggul diantara sekolah-sekolah yang lain dan merupakan landasan utama sebuah sekolah, sebab dengan adanya visi dan misi maka arah didirikannya sekolah dapat dilalui sehingga mampu mencapai tujuan yang diinginkan.

Dalam usia yang relatif muda yaitu sekitar 7 tahun, SMP Al-Mujahidin telah tumbuh menjadi sekolah yang memiliki banyak prestasi baik akademik maupun non akademik. Pada tahun 2018 sekolah ini ditetapkan sebagai salah satu "SEKOLAH 
RUJUKAN', Nasional bersama 260 sekolah dari 38.960 SMP se Indonesia. Selama enam tahun ini telah meraih 381 prestasi meliputi 19 prestasi tingkat internasional, 25 prestasi tingkat nasional, 45 prestasi tingkat propinsi, 175 prestasi tingkat kabupaten, 117 prestasi tingkat kecamatan. Kondisi ini telah menjadikan sekolah ini menjadi sekolah pavorit dan diakui masyarakat dari tahun ke tahun, minat masyarakat untuk menyekolahkan putra-putrinya ke sekolah ini selalu meningkat.

Berdasarkan hasil wawancara dengan para partisipan, diketahui bahwa kunci keberhasilan SMP Muhammadiyah Al Mujahidin dalam membangun kepercayaan masyarakat tidak lepas dari peran kepemimpinan kepala sekolah yang memiliki beberapa strategi sebagai berikut : 1) penyampaian visi dan misi yang jelas, 2) mendorong guru untuk meningkatkan profesioanalismenya, 3) menciptakan lingkungan yang kondusif, 4) pembelajaran yang ramah siswa, 5) membangun manajemen yang kuat, 6) menciptakan kurikulum yang luas tapi seimbang, 7) penilaian dan pelaporan prestasi siswa yang bermakna, serta 8) pelibatan orang tua dan masyarakat. Secara lebih rinci kedelapan strategi tersebut dapat dilihat dalam paparan berikut ini:

1) Penyampaian visi dan misi sekolah yang jelas

Kepala SMP Muhammadiyah Al Mujahidin, menyampaikan kepada seluruh warga sekolah bahwa visi misi sekolah itu penting dan wajib dipahami, dan dilaksanakan dalam setiap aktifitasnya disekolah. Oleh karena itu, sebagai seorang pemimpin, kepala sekolah berupaya untuk menyampaikan visi misi sekolah kepada seluruh stake holder maupun masyarakat secara umum. Proses penyampaian visi misi yang dilakukan oleh kepala sekolah SMP Muhamamdiyah Al Mujahidin adalah sebagai berikut:

a.

Menyampaikan visi misi kepada orang tua wali siswa pada rapat pertemuan orang tua wali murid setiap tahunnya.

b. Membuat baliho yang bertuliskan visi misi sekolah dan menempelkannya di lingkungan sekolah

c. Menyampaikan visi misi sekolah dalam setiap kegiatan dan program yang diadakan sekolah agar tercipta budaya komunikasi yang efektif antara strekholder dan masyarakat secara umum.

Berdasarkan hasil penelitian diketahui bahwa keberhasilan SMP Muhamamdiyah Al-Mujahidin untuk mendapatkan kepercayaan masyarakat sehingga dari tahun ke tahun jumlah siswa terus bertambah karena faktor kepemimpinan kepala sekolah yang inovatif. Dalam hal ini, kepala SMP Muhammahdiyah Al-Mujahidin telah berhasil membentuk system pendidikan yang memberikan jaminan mutu pendidikan yang baik bagi para lulusannya.

Salah satu upaya yang dilakukan oleh kepala sekolah untuk menarik minat masyarakat terhadap SMP Muhammadiyah Al-Mujahidin, kepala sekolah mengambil tindakan untuk menyampaikan visi misi sekolah kepada seluruh stakeholder dan masyarakat luas. Program ini terbukti telah menjadikan SMP Muhammadiyah AL Mujahidin semakin dikenal dan dipercaya oleh masyarakat sebagai sekolah unngulan yang mengedepankan ajaran tauhid Islam. Strategi ini menunjukan bahwa kepala 
sekolah merupakan pemimpin yang visioner dan memahami memahami budaya sekolah (Mombourquette, 2017). Hubungan antara kepemimpinan dan penciptaan budaya sekolah yang sama tergantung pada kehadiran dan kekompakan kelompok individu yang berinteraksi.

Kunci dari gagasan ini adalah bahwa kepala sekolah memiliki kebebasan untuk bekerja dengan guru untuk membentuk budaya sekolah yang positif. Kepala sekolah memberikan dukungan untuk pengembangan budaya positif ini dengan memfasilitasi identifikasi dan pelestarian apa yang berharga sambil bekerja untuk mengurangi faktor budaya yang tidak mendukung pembelajaran siswa. Ketika dilakukan dengan benar, kepemimpinan instruksional kepala sekolah berpadu dengan budaya sekolah dan bersama-sama mereka membentuk kekuatan yang kuat untuk berdampak positif pada pembelajaran siswa. Budaya sekolah yang akan dibangun, semua tercermin dalam visi misi sekolah (Fitrah et al., 2020), sehingga pengenalan visi misi sekolah secara jelas merupakan bagian dari pengenalan budaya sekolah yang ditawarkan kepada masyarakat.

Ketika kepala sekolah ditanya tentang visi sekolah masing-masing, dicatat bahwa semua mampu mengartikulasikan apa yang mereka anggap sebagai kekuatan pendorong sekolah. Mereka tidak serta merta mengutip visi sekolah yang dicetak dan disetujui secara resmi. Sebaliknya, mereka membahas gagasan besar tentang visi dari sudut pandang apa yang umumnya dianggap sebagai fitur yang membuat sekolah mereka unik. Pengenalan visi sekolah dapat meningkatkan performance sekolah di mata masyarakat (Kantabutra, 2005).

2) Mendorong guru untuk meningkatkan professionalismenya

Guru juga memegang peranan penting dalam pendidikan khususnya dalam memberikan pembelajaran, guru yang professional tentunya akan menghasilkan siswa yang berkualitas juga. SMP Muhammadiyah Al Mujahidin mengadakan rekrumen guru sehingga guru yang ada di SMP Muhammadiyah Al Muajhidin benarbenar berkualitas sesuai kompetensi yang dibutuhkan oleh sekolah. Selain itu juga guru-guru didorong untuk mempunyai prestasi membanggkan. Kepala sekolah memberikan kesempatan kepada bapak ibu guru untuk mengikuti even-even lomba sesuai dengan kompetensi dan bidang masing-masing dari tingkat Kabupaten, Propinsi bahkan sampai tingkat internasional, guru yang berprestasi juga diberikan beasiswa untuk menlanjutkan studi ketingkat selanjutnya agar lebih meningkatkan kompentsi serta pendidikannya. Guru yang terseleksi dan berkualitas ini tentunnaya akan menghasilkan siswa yang berprsetasi pula. Sumber dana yang digunakan dalam meningkatkan profesionalisme guru ini di ambilkan dari sumber pembiayaan sekolah di SMP Muhammadiyah al Mujahidin meliputi iuran komite, BOS, Iuran komite meliputi IPP (Infaq Penyelenggaraan Pendidikan), IPK (Infaq Penyelenggaraan Kampus), UKT (Uang Kegiatan Tahunan), SP (Sumbangan Pendidikan) dan AJ (Amal Jariyah).

Kualitas sumber daya manusia ditentukan oleh mutu dan tingkat pendidikan. Kualitas pendidikan yang rendah menyebabkan kualitas sumber daya manusia 
rendah; makin tinggi tingkat pendidikan maka makin tinggi pula kualitas sumber daya manusia. Profesionalisme guru tercermin pada pelaksanaan tugas yang ditandai dengan keahlian baik dalam materi maupun metode. Profesional hendaknya mampu memikul dan melaksanakan tanggung jawab sebagai guru kepada pesertadidik, orang tua, masyarakat, bangsa negara, dan agamanya (Yusutria, 2017).

Guru di SMP Muhammadiyah Al Mujahidin memiliki kompetensi yang berkualitas. Selain itu juga guru-guru mempunyai prestasi membanggkan ini di buktikan dengan beberapa guru menjuarai lomba-lomba sebagai contoh adalah Bapak Hanasto, SPdI, M.S.I menjuarai lomba Aplikasi Mobile Pembelajaran Ki Hajar tingkat Propinsi pada tahun 2018, Penulisan naskah kultum Olympicad tingkat Kabupaten Gunungkidul, mendapatkan medali emas lomba majalah sekolah, tahun 2019 dan 2020 Juara 1 dan 2 pembuatan aplikasi mobile tingkat kabupaten Gunungkidul.Dengan guru dan tenaga kependidikan yang semuanya pilihan dan berkualitas ini tentunnaya akan menghasilkan siswa yang berprestasi pula.

Sikap bersaing dapat dibangun melalui kepemimpinan yang kuat dan gigih sehingga hal tersebut akan mampu juga meningkatkan motivasi guru-guru dalam meningkatkan kompetensinya dalam mengahadapi persaingan yang ada, ini sudah dibuktikan dengan prestasi yang diperoleh guru-guru di SMP Muhammadiyah Al Mujahidin. Pengembangan kualitas dan profesionalisme guru secara baik dipastikan akan mewujudkan mutu dan kualitas pendidikan. (Yusutria, 2017).

3) Menciptakan lingkungan yang kondusif

Agar para siswa merasa aman dan nyaman dalam proses pembelajaran SMP Muhammadiyah Al Mujahidin dilengkapi dengan sarana prasarana menunjang kebutuhan belajar siswa dalam kegiatan kurikuler maupun ekstrakurikuler yaitu memiliki ruangan kelas ber AC dan dilengkapi LED TV, Lab IPA, Lab Komputer, Perpustakaan Multimedia. Memiliki 4 Kampus sebagai Pusat Pembelajaran, dengan fasilitas yang bagus ini tentunya juga membawa daya tarik tersendiri bagi masyarakat. Menurut Kepala Sekolah SMP Muhammdiyah Al Mujahidin awal dulu ketikan memperkenalkan sekolah kepada siswa atau masyarakat yang di unggulkan adalah bahwa sekolah memilki fasilitas ruang kelas ber Ac dengan dilengkapi TV, sehingga siswa dan masyarakat tertarik untuk menyekolahkan putra-putrinya di SMP Muhammdiyah Al Mujahidin ini, pada masa itu memang sekolah di kabupaten Gunungkidul belum ada yang memiliki ruang kelas seperti yang dimiliki oleh SMP Muhammdiyah Al Mujahidin.

Keberhasilan siswa dalam pembelajaran tentunya dipengaruhi oleh lingkungan yang kondusif sehingga siswa akan merasa aman, nyaman dalam menerima pembelajaran. Berdasarkan penuturan salah satu wali siswa SMP Muhammadiyah Al Mujahidin bahwa sekolah memiliki gedung yang bagus,bersih,rapi dengan sarana prasarana yang menunjang kebutuhan belajar serta dilengkapi dengan pagar dan gerbang,sehingga anak-anak akan aman dan nyaman walaupun sekolahan berada di pinggir jalan raya. 
Menurut Wahyu Suraksumah dalam Atwool (1999) menyatakan bahwa lingkungan pembelajaran sekolah, dimana siswa mempunyai kesempatan untuk melakukan hubungan yang bermakna di dalam lingkungan sekolahnya, sangat diperlukan untuk meningkatan kemampuan belajar siswa, memfasilitasi siswa untuk bertingkah laku yang sopan, serta berpotensi untuk membantu siswa dalam menghadapi masalah yang dibawa dari rumah.

Mengingat pentingnya lingkungan kelas pembelajaran, Les Gallay \& Suet-Ling Pong (2004), menyimpulkan bahwa iklim kelas dapat mempengaruhi pencapaian prestasi akademik dan non akademik. Di samping itu, penelitian yang dilakukan oleh Silalahi (2008) menunjukkan bahwa iklim (lingkungan) kelas juga berpengaruh terhadap motivasi belajar. Bahwa situasi, suasana atau kondisi lingkungan, baik sekolah maupun di kelas sangat penting untuk pencapaian target akademik maupun non akademik (Harjali, 2017). Kelas yang kondusif dapat menghindarkan siswa dari kejenuhan, kebosanan dan kelelahan psikis sedangkan disis lain kelas yang kondusif akan dapat menumbuhkan minat motivasi dan daya tahan belajar (Arianti, 2019).

4) Pembelajaran yang ramah siswa

Proses kegiatan pembelajaran di SMP Muhammdiyah Al Mujahidin adalah pembelajaran yang ramah siswa adalah dengan pembelajaran yang menyesuaikan dengan kondisi siswa dengan mengembangkan delapan kecerdasan yang dimilki siswa, multi strategi serta multi intelegences diharapkan siswa dapat mengeksplorasi, mengkomunikasikan, mengamati, mempraktekan dan mendiskusikan sesuai dengan bakat dan minat yang dimiliki oleh siswa tersebut. Kepala Sekolah mengatakan bahwa siswa pintar itu tidak hanya pintar secara science maupun matematik tetapi anak dapat mengembangkan bakat seperti kecerdasan linguistik, musical, kinestetik, interpersonal, intrapersonal, spasial, gerak dan lain-lain. dalam proses pembelajaran ini bertujuan agar siswa itu belajar untuk mendapat pengalaman serta sebuah karya dengan siswa berekspresi dengan kreatifitasnya.

Sekolah membuat program yaitu Program Bina Prestasi "One Student One Tropy" dan program Apresiasi Cipta Adi Karya. Program ini difokuskan untuk membimbing siswa mempersiapakan berbagai perlombaan yang akan dikuti oleh siswa. Bentuk bimbingan ada dua bentuk yaitu bimbingan reguler dan bimbingan intensif. Bimbingan reguler dilakukan 20x pertemunan, bimbingan intesif adalah pembinaan secara lebih mendalam dilaksanakan selama 2 minggu sebelum pelaksanaan lomba dimulai.

Menurut penuturan Kepala SMP Muhammadiyah Al Mujahidin program ini untuk terwujudnya siswa yang berprestasi sesuai bakat minat, satu siswa satu piala. Tujuan penyusunan program ini adalah sebagai acuan dan pemetaan dalam pembinaan prestasi siswa dalam mempersiapkan even-even kompetisi sehingga terwujudnya pelaksanaan bina prestasi yang efektif dan efisien.

Pada tahun pelajaran 2020/2021 berdasarkan hasil evaluasi program one student one tropy perlu dipetakan berbagai perlombaan sekolah untuk mewadahi para siswa yang belum berprestasi dalam kompetisi luar sekolah. Hal ini akan lebih 
meningkatkan jumlah perolehan piala prestasi siswa dalam even lomba sekolah yang dapat meningkatkan semangat belajar siswa. Program Apresiasi Cipta Adi Karya juga dikembangkan sebagai wadah para siswa yang belum bisa meraih prestasi akademik maupun prestasi kompetensi di luar sekolah agar menciptakan karya yang berharga.

Guru juga memegang peranan penting dalam pendidikan khususnya dalam memberikan pembelajaran. Pembelajaran yang ramah siswa adalah dengan pembelajaran yang menyesuaikan dengan kondisi siswa. Program ini tidak lepas dari peran serta guru dalam mendidik dan membimbing siawa dalam kegiatan pembelajaran.

Pendidikan dapat dikatakan ramah anak apabila dengan melihat kondisi lingkungan belajar yang aman, nyaman, dan penuh kasih sayang sebab hubungan yang terjalin dengan rasa cinta dan kasih sayang antara anak dengan guru, orang tua, maupun sesama teman sebayanya sangat berpengaruh dalam membentuk karakter seorang anak (Yulianto, 2016).

5) Membangun manajemen yang kuat

SMP Muhammadiyah Al Mujahidin pembentukan manajemen yang kuat dengan melibatkan berbagai pihak yaitu kepala sekolah, guru, yayasan, komite sekolah, orang tua hingga masyarakat untuk membantu mempromosikan dengan menunjukan keunggulan sekolah, melalui musyawarah untuk menyususn dan merumuskan berbagai program sekolah melalui panitia kecil atau tim untuk merumuskan program kerja kemudian disampaikan kepada semua komponen sekolah melalui rapat kerja dilakukan revisi program kerja. Di dalam pembuatan program kerja sudah dilengkapi mulai dari perencanaan, pelaksanaan, penganggaran biaya, pihak yang melaksanakan program kerja tersebut dan diadakan evaluasi terhadap target dan sasaran yang telah tercapai. Teknis pelaksanaan program kegiatan sekolah tersebut diserahkan kepada koordinator masing-masing. Dalam pelaksanaannya, kepala sekolah menggunakan sistem kontrol dengan menjalin komunikasi intensif dengan koordinator kegiatan. Sistem lain yang diterapkan oleh kepala sekolah SMP Al-Mujahidin adalah dengan melakukan pengamatan, pengawasan, dan pengecekan secara berkala. Kepala Sekolah melihat setiap proses yang terjadi secara langsung, melihat setiap dokumen-dokumen yang ada,hasil dari pengawasan tersebut selanjutnya dapat dijadikan sebagai rujukan bagi Kepala Sekolah dalam mengevaluasi setiap program kegiatan, proses adalah pertama, dengan cara melakukan konfirmasi dan koordinasi langsung dengan koordinator program yang diberi tanggung jawab suatu kegiatan, pada koordinasi ini kepala sekolah bisa mendengar langsung proses awal sampai dengan akhir semua kegiatan, termasuk persoalan yang muncul dan solusi yang diambil. Kedua, melakukan monitoring dan pengawasan dengan langsung memantau dan melihat sendiri kegiatan yang sedang dilakukan, dan apabila menemukan kejanggalan atau ada problem yang muncul pada saat memantau langsung, kepala sekolah langsung memanggil koordinator program yang diberi tanggungjawab untuk bermusyawarah mencari sebab dan solusinya. Dan 
cara yang ketiga, apabila kepala sekolah tidak bisa memantau langsung dan kebetulan tidak ada di sekolah karena melaksanakan tugas luar, maka kepala sekolah melakukan pengawasan dan pemantauan melalui media telekomunikasi, minimal melalui whatsapp, dan CCTV 3G yang bisa dipantau jarak jauh mengunakan $\mathrm{HP} / \mathrm{smartphone.}$

Manajemen sekolah merupakan proses pemanfaatan seluruh sumber daya sekolah yang dilakukan melalui tindakan yang rasional dan sistematik (mencakup perencanaan, pengorganisasian, pengerahan tindakan, dan pengendalian) untuk mencapai tujuan sekolah secara efektif dan efisien. Tindakan-tindakan manajemen tersebut bersumber pada kebijakan dan peraturan-peraturan yang disepakati bersama yang diwujudkan dalam bentuk sikap, nilai, dan perilaku dari seluruh orang yang terlibat di dalamnya (Sulfemi \& Arsyad, 2019).

Pembentukan manajemen yang kuat dengan melibatkan berbagai pihak yaitu kepala sekolah, guru, yayasan, komite sekolah, orang tua hingga masyarakat untuk membantu mempromosikan dengan menunjukan keunggulan sekolah.

Di SMP Muhammadiyah Al Mujahidin melalui peran kepala sekolah yang memiliki kemampuan secara holistik yang baik sehingga mampu menggerakan seluruh komponen sekolah sebagai sebuah sistem, mampu membangun manajemen sekolah sehingga mengantarkan sekolah menjadi sekolah favorit yang berprestasi secara akademik maupun non akademik serta mampu bersaing dengan sekolahsekolah yang lain di Kabupaten Gunungkidul.

Berdasarkan keberhasilan sekolah tersebut,dalam mencapai target tinggi yang telah ditetapkannya sendiri maka sekolah tersebut disebut sebagai Sekolah unggul dan efektif (Sulfemi \& Arsyad, 2019).

6) Menciptakan kurikulum yang luas tapi seimbang

Kurikulumnya SMP Muhammadiyah Al Mujahidin diperkaya dengan pengembangan dan improvisasi, Sekolah memiliki muatan kurikulum sesuai pemerintah ditambah dengan kurikulum agama serta pembiasaan budaya Islami disetiap kegiatan sekolah kurikulum tersebut dikembangkan menjadi Program terbagi menjadi empat dan menjadi bagian dari program unggulan yang belum dimiliki oleh sekolah lain. Diantaranya adalah pertama program akademik yang terdiri dari KBM Intensif dengan multimedia, bimbingan belajar UN, klinik akademik, bimbingan khusus One Day Before Examination (ODBE), layanana bimbingan privat, pembimbitan dan bimbingan olimpiade; kedua program keislaman terdiri dari program incidental (pesantren ramadhan dan pengajian), golden habits islami, tahfidzul qur'an, tahsinul qur'an, kultum 4 bahasa dan khutbah jum'at; ketiga program pengembangan seperti mujahidin adventure, mujahidin magz, student exchange, robotik (club robotic), study tour, field study/out door learning, sekolah sepak bola. SMP Muhammadiyah Al-Mujahidin melihat terdapat peluang untuk melakukan terobosan dalam melaksanakan program unggulan ini. Dan ternyata hasilnya cukup membanggakan, sebab setelah memiliki program unggulan, banyak anak yang tertarik bersekolah di SMP Muhammadiyah Al-Mujahidin dan tentunya 
hal ini pula dibarengi dengan diprolehnya prestasi yang sangat membanggakan selama ini, bukan hanya melalui ekstrakurikuler, SMP Muhammadiyah AlMujahidin juga mendorong dan memfasilitasi para siswa-siswanya untuk berprestasi di bidang akademik dan non-akademik. Selain sebagai ajang promosi kenggulan sekolah. Tujuan lain dari upaya ini adalah melatih mental anak. Tentunya hal ini menjadi pengalaman yang akan selalu berkesan pada diri anak. Berdasarkan percakapan Bapak Jaka Prayitna, S.Pd.I dengan Bapak Hanasto, S.Pd.I selaku Guru SMP Muhammadiyah Al-Mujahidin.

Pengembangan kurikulum adalah perencanaan kesempatan-kesempatan belajar yang dimaksudkan untuk membawa siswa ke arah perubahan-perubahan yang diinginkan dan menilai hingga mana perubahan-perubahan itu telah terjadi pada diri siswa (Mubarak, 2013)

7) Penilaian dan pelaporan prestasi siswa yang bermakna

Pelaksanaan proses penilian dan pelaporan prestasi siswa SMP Muhammdiyah Al Mujahidin melalui program sekolah yaitu Bina Prestasi One Student one Tropy dan Apresiasi Adi Karya. Para siswa belajar menghasilkan sebuah karya dan itu sebagai proses penilaian sekolah, serta hasil karya siswa di pamerkan sebagai ajang award setiap tahun sekali, sehingga dengan cara seperti ini para siswa akan berlomba-lomba untuk menghasilkan karya terbaik. kepala sekolah menyampaikan bahwa di SMP Al-Mujahidin prestasi peserta didik itu sangat penting, karena ini ada hubungannya dengan keberlangsungan sekolah.

Mengelola kelas yang efektif dengan cara mendesain lingkungan fisik kelas untuk pembelajaran yang optimal, menciptakan lingkungan yang positif untuk pembelajaran, membangun dan menegakkan aturan, mengajak siswa untuk bekerja sama, mengatasi problem secara efektif, dan mengunakan strategi komunikasi yang baik (Santrock, 2010). Guru memiliki peranan penting terhadap proses pembelajaran di kelas, guru-guru yang muda dan kreatif akan menciptakan suasana pembelajaran yang sangat menarik dan menyenangkan dengan berbagai variasi model dan metode pembelajaran.

SMP Muhammadiyah Al Mujahidin membuat program yang di gunakan sebagai bagian dari hasil belajar ataupun karya yang dilahirkan dari tugas-tugas pembelajaran yang di dapatnya di sekolah dengan mengeksplorasi dari delapan kecerdasan majemuk dari siswanya. Program Apresiasi Cipta Adi Karya merupakan salah satu program yang dibuat oleh sekolah yang dilatar belakangi oleh pemikiran bahwa banyak tugas-tugas pembelajaran di sekolah yang menghasilkan karya orisinil yang patut untuk diapresiasi untuk mendukung tumbuh kembang kecerdasan anak.

Apresiasi karya ini diwujudkan dalam bentuk pemeran karya siswa dan kegaitan award untuk menghasilkan karya terbaik. Pameran karya atau award ini dilaksanakan setiap satu tahun sekali bersamaan dengan wisuda tahfidz dan pelepasan siswa kelas 9, karya yang dipamerkan adalah hasil karya siswa yang di wisuda, dengan demikian selain untuk mengasah bakat dan minat siswa dalam 
sebuah karya program ini juga dijadikan sebagai bahan penilaian dan pelaporan prestasi siswa yang bermakna.

8) Pelibatan orang tua dan masyarakat

Kepala sekolah menjelaskan dalam wawancaranya bahwa SMP Muhammadiyah Al Mujahidin mampu bekerjasama dengan baik, memiliki hubungan yang harmonis didalam sekolah maupun diluar sekolah dengan para stakeholder, salah satu contohnya adalah melalui program kegiatan Golden Habits Islami ini Sekolah bekerja dengan orang tua untuk saling mengontrol kegiatan anak terkait dengan pembiasaan ini, jika program ini dilaksanakan dengan baik Insya Allah akan bisa memberikan contoh kepada mereka sehingga pembiasaan positif ini bisa tertanam dalam pribadi masing-masing siswa dan keluarga besar SMP Muhammadiyah Al Mujahidin. Orang tua dan masyarakat selalu dilibatkan dalam setiap kegiatan atau program sekolah sehingga mereka membantu mempromosikan dengan menunjukan keunggulan sekolah kepada masyarakat luas.

Kerjasama dengan orang tua dan masyarakat perlu diusahakan untuk terciptanya lingkungan belajar yang kondusif dan menyelaraskan program yang tertuang dalam kurikulum disekolah dengan lingkungan anak dirumah. Kerjasama yang efektif dan komunikasi dengan orang tua sangat diperlukan dalam hal yang terkait dengan kepentingan dan perkembangan anak. Orangtua perlu mengetahui keadaan anak mereka dari unsur sekolah, dan manfaat bagi guru adanya komunikasi dengan orang tua siswa, diantaranya untuk memahami perilaku anak di rumah dari masukan orang tua siswa (U. Hasanah, 2017).

Saat ini pelibatan orang tua dalam penyelenggaraan pendidikan sangat penting. Orang tua adalah bagian dari masyarakat yang harus membantu sekolah, baik bantuan dana, pemikiran bahkan support pada sekolah. Keterlibatan orang tua dalam penyelenggaraan pendidikan akan mendorong sekolah untuk meningkatkan kinerjanya, karena orang tua juga dapat berperan sebagai pemantau pelaksana pendidikan.

Kerjasama orang tua sangat penting, sebab lewat komunikasi dengan pihak sekolah maka orang tua dapat memahami proses penyelenggaraan pendidikan yang ada di sekolah (Hidayat, 2013; Ishimaru, 2014). Oleh karena itu berbagai program, baik kegiatan belajar-mengajar/intrakurikuler, memberikan tugas rumah kepada siswa/kokurikuler serta latihan kepemimpinan dan pembinaan siswa/ekstrakuriler dapat berjalan lancar dan tidak terjadi miskomunikasi antara orang tua dengan pihak sekolah. Ketika guru bertindak mendisiplinkan siswa, orang tua tidak komplain karena memahami tentang proses pendidikan yang sementara berlangsung. Agar pelibatan orang tua maksimal, pihak sekolah harus mensosialisasikan semua program sekolah tiap tahun ajaran baru serta menyusun program-program tersebut bersama orang tua (Özdamlı \& Yıldız, 2014).

Realita yang dapat kita temui bahwa sebagian besar sekolah yang memiliki prestasi kesenian, olimpiade sains baik daerah, nasional dan internasional biayapembiayaannya diupayakan pihak sekolah lewat bantuan orang tua. Selain itu, lewat 
keterlibatan orang tua dalam penyelenggaraan pendidikan dapat membangun ekosistem pendidikan yang mampu menumbuhkembangkan karakter anak bangsa yang bermoral dan beretika. Dalam arti, pendidikan yang berkarakter akan menciptakan manusia yang bukan hanya sekedar terpelajar tetapi juga harus terdidik. Sehingga pendidikan yang merupakan syarat mutlak bagi setiap orang yang mengharapkan hidup lebih baik itu benar-benar terlaksana bahkan berdampak pada kemajuan bangsa Indonesia.

Berdasarkan paparan diatas menunjukkan bahwa kepala sekolah memegang peranan penting dalam menentukan maju mundurnya sekolah, dalam hal PPDB seorang kepala sekolah harus mempunyai strategi yang jitu untuk menarik siswa sebanyak-banyak, dan ini dibuktikan oleh Kepala Sekolah SMP Muhammdiyah Al Mujahidin bahwa kepercayaan masyarakat terhadap sekolah tersebut melalui peningkatan jumlah siswa setiap tahunnya, serta peningkatan kualiatas dan mutu sekolah tersebut. Selain itu juga karena kepemimpinan (Thoha, 2016) kepala sekolah tersebut dalam mengendalikan seluruh stekholder dalam melaksanakan program sekolah, termasuk program kegaiatan PPDB ini. Secara sederhana, efek setiap strategi yang dilakukan oleh kepala sekolah SMP Muhammadiyah Al Mujahidin dalam meningkatkan minat masyarakat dapat dilihat dalam tabel 1 berikut ini:

\section{Tabel 1}

\begin{tabular}{|c|c|c|}
\hline \multicolumn{3}{|c|}{ Hasil Penerapan Strategi Sekolah dalam Meningkatkan Minat Masyarakat } \\
\hline No & $\begin{array}{l}\text { Strategi kepemimpinan kepala } \\
\text { sekolah }\end{array}$ & Hasil dari penerapan kebijakan \\
\hline 1 & Pengenalan visi misi yang jelas & $\begin{array}{l}\text { Sekolah semakin dikenal, } \\
\text { semakin paham tentang } \\
\text { sekolah dan meningkatkan } \\
\text { serformateristik } \\
\text { sekolah }\end{array}$ \\
\hline 2 & $\begin{array}{l}\text { Mendorong guru untuk } \\
\text { meningkatan Profesionalisme }\end{array}$ & $\begin{array}{l}\text { Sekolah memiliki guru-guru yang } \\
\text { berprestasi sehingga secara otonmatis dapat } \\
\text { mengembangan kualitas dan mutu } \\
\text { pendidikan sekolah tersebut }\end{array}$ \\
\hline 3 & $\begin{array}{l}\text { Menciptakan lingkungan yang } \\
\text { Kondusif }\end{array}$ & $\begin{array}{l}\text { Sekolah memliki pencapaian prestasi baik } \\
\text { akademik maupun non akademik, } \\
\text { menumbuhkan motivasi dan daya tahan } \\
\text { belajar }\end{array}$ \\
\hline 4 & Pembelajaran yang ramah anak & $\begin{array}{l}\text { Sekolah mengembangkan } \\
\text { kecerdasan yang dimilki siswa, pemetaan } \\
\text { dalam pembinaan prestasi siswa }\end{array}$ \\
\hline 5 & $\begin{array}{l}\text { Membangun manajemen yang } \\
\text { baik }\end{array}$ & $\begin{array}{l}\text { Kepemimpinan kepala sekolah yang holitisk } \\
\text { menghasilkan sekolah yang unggul dan } \\
\text { efektif }\end{array}$ \\
\hline 6 & $\begin{array}{l}\text { Menciptakan kurikulum yang luas } \\
\text { tapi seimbang }\end{array}$ & $\begin{array}{l}\text { Sekolah memiliki kurikulum yang } \\
\text { diperkaya dan improvisasi sehingga sekolah } \\
\text { mempunyai peluang untuk melakukan } \\
\text { terobosan dalam melaksanakan dan }\end{array}$ \\
\hline
\end{tabular}




\begin{tabular}{|c|c|c|}
\hline No & $\begin{array}{c}\text { Strategi kepemimpinan kepala } \\
\text { sekolah }\end{array}$ & Hasil dari penerapan kebijakan \\
\hline & & mempromosikan keunggulan sekolah \\
\hline 7 & $\begin{array}{l}\text { Penilaian dan pelaporan prestasi } \\
\text { siswa yang bermakna }\end{array}$ & $\begin{array}{l}\text { Sekolah menghasilkan sebuah program } \\
\text { Apresiasi Cipta Adi Karya sebagai ajang } \\
\text { untuk mengasah bakat dan minat siswa } \\
\text { dalam sebuah karya }\end{array}$ \\
\hline 8 & $\begin{array}{llll}\text { Pelibatan } & \text { orang } & \text { tua } & \text { dan } \\
\text { masyarakat } & & & \end{array}$ & $\begin{array}{l}\text { Sekolah menciptakan ekosistem pendidikan } \\
\text { yang mampu menumbuhkembangkan } \\
\text { karater yang bermoral dan beretika. }\end{array}$ \\
\hline
\end{tabular}

\section{Kesimpulan}

Keberhasilan SMP Muhamamdiyah Al-Mujahidin untuk mendapatkan kepercayaan masyarakat sehingga dari tahun ke tahun jumlah siswa terus bertambah karena faktor kepemimpinan kepala sekolah yang inovatif. Dalam hal ini, kepala SMP Muhammahdiyah Al-Mujahidin telah berhasil membentuk system pendidikan yang memberikan jaminan mutu pendidikan yang baik bagi para lulusannya.

Kepala sekolah memegang peranan penting dalam menentukan maju mundurnya sekolah, dalam hal PPDB seorang kepala sekolah harus mempunyai strategi yang jitu untuk menarik siswa sebanyak-banyak, dan ini dibuktikan oleh Kepala Sekolah SMP Muhammdiyah Al Mujahidin bahwa kepercayaan masyarakat terhadap sekolah tersebut melalui peningkatan jumlah siswa setiap tahunnya,serta peningkatan kualiatas dan mutu sekolah tersebut. Selain itu juga karena kepemimpinan (Thoha, 2016) kepala sekolah tersebut dalam mengendalikan seluruh stekholder dalam melaksanakan program sekolah, termasuk program kegaiatan PPDB ini. Secara sederhana, efek setiap strategi yang dilakukan oleh kepala sekolah SMP Al-Mujahidin dalam meningkatkan minat masyarakat melalui beberapa strategi. 


\section{BIBLIOGRAFI}

Ainscow, M., Muijs, D., \& West, M. (2006). Collaboration as a strategy for improving schools in challenging circumstances. Improving Schools, 9(3), 192-202.

Amini, A., \& Ginting, N. (2020). Otonomi Pendidikan Di Masa Krisis Pandemi Covid19 (Analisis Peran Kepala Sekolah). Al-Muaddib: Jurnal Ilmu-Ilmu Sosial Dan Keislaman, 5(2), 305-314.

Arianti. (2019). Urgensi Lingkungan Belajar yang Kondusif dalam Mendorong Siswa Belajar Aktif. Didaktika: Jurnal Kependidikan, 11(1), 41-62.

Arikunto, S. (2010). Metode peneltian. Jakarta: Rineka Cipta..

Caldwell, B. J. (2015). School Management. In International Encyclopedia of the Social \& Behavioral Sciences: Second Edition.

Citra Resmi, U. D., \& Hasanah, E. (2020). Best Practice Leadership of The Principal in Covid-19 Prevention Primary School at SD Muhammadiyah Purbayan. Randwick International of Education and Linguistics Science Journal.

Ekosiswoyo, R. (2016). Kepemimpinan Kepala Sekolah yang Efektif Kunci Pencapaian Kualitas Pendidikan. Jurnal Ilmu Pendidikan, 14(2), 76-82.

Fatah, N. (2004). Landasan Manajemen Pendidikan. Bandung: Rosdakarya.

Ferlie, E., McGivern, G., \& De Moraes, A. (2010). Developing a public interest school of management. British Journal of Management, 21, s60-s70.

Fitrah, H., Suyanto, S., Sugiharsono, S., \& Hasanah, E. (2020). Developing a School Culture through Malamang Culture in Indonesia. Universal Journal of Educational Research, 8(12), 6667-6675.

Hammer, P. C. (2016). Catalyst Schools' Implementation of the Learning School Approach. Catalyst Schools Research Study Report. West Virginia Department of Education Office of Research, Accountability, and Data Governance.

Harjali, H. (2017). Strategi guru dalam membangun lingkungan belajar yang kondusif: studi fenomenologi pada kelas-kelas sekolah menengah pertama di Ponorogo. Jurnal Pendidikan dan Pembelajaran (JPP), 23(1), 10-19.

Hasanah, e., zamroni, z., dardiri, a., \& supardi, S. (2019). Indonesian adolescents experience of parenting processes that positively impacted youth identity. The qualitative report. 24(3), 499-512.

Hasanah, E. (2019). Perkembangan Moral Siswa Sekolah Dasar Berdasarkan Teori Kohlberg. JJournal UNY, 6(2), 131-145. 
Hasanah, U. (2017). Analisis Praktik Pelibatan Orang Tua dan Masyarakat dalam Kegiatan Kreatif Anak Usia Dini: Studi Kasus di TK Pertiwi Ds. Tambah Rejo, Kec. Tunjungan Kab. Blora. Nadwa, 11(2), 177-198.

Hasim, W., \& Hasanah, E. (2020). The Role of Principal Leadership in Preventing COVID-19 Transmission at SMA Muhammadiyah 2 Karang Tengah Buay Madang Timur Indonesia. Asian Journal of Education and Social Studies. https://doi.org/10.9734/ajess/2020/v11i130279

Hidayat, H. S. (2013). Pengaruh Kerjasama Orang Tua dan Guru Terhadap Disiplin Peserta Didik di Sekolah Menengah Pertama (SMP) Negeri Kecamatan Jagakarsa Jakarta Selatan. Jurnal Ilmiah Widya.

Ishimaru, A. M. (2014). When new nelationships meet old narratives: The journey towards improving parent-school relations in a district-community organizing collaboration. Teachers College Record.

Junaidi, J. N. (2019). Strategi Kepala Sekolah dalam Rekrutmen Penerimaan Peserta Didik Baru Di Sekolah Menengah Atas Negeri 5 Merangi. UIN Jambi.

Kantabutra, S. (2005). Improving public school performance through vision-based leadership. Asia Pacific Education Review, 6(2), 124-136.

Marsiti. (2011). Strategi Kepala Sekolah dalam Implementasi Sistem Manajemen Mutu ISO 9001. UIN Alaudin.

Matthew, B. M. (1994). Huberman. A Michael. Qualitative Data Analysis: An Expanded Source Book (Thousands Oks, CA: Sage Publications.

Moleong, L. J. (2018). Metode Penelitian Kualitatif. Bandung: PT. Remaja Rosdakarya. Mombourquette, C. (2017). The Role of Vision in Effective School Leadership. International Studies in Educational Administration (Commonwealth Council for Educational Administration \& Management (CCEAM)), 45(1).

Mubarak, R. (2013). Pengembangan Kurikulum Sekolah Dasar. Madrasah: Jurnal Pendidikan Dan Pembelajaran Dasar, 5(2), 24.

Mulyasana, D. (2011). Pendidikan Bermutu dan Berdaya Saing. Bandung: Rosda Karya.

Nawaz Khan, S., \& Qureshi, I. M. (2010). Impact of Promotion on Students' Enrollment: A Case of Private Schools in Pakistan. International Journal of Marketing Studies. https://doi.org/10.5539/ijms.v2n2p267

Özdamlı, F., \& Yıldız, E. P. (2014). Parents' Views towards Improve Parent-School Collaboration with Mobile Technologies. Procedia - Social and Behavioral Sciences. https://doi.org/10.1016/j.sbspro.2014.04.130 
Patton, M. Q. (2012). Qualitative research and evaluation methods (3rd ed.). Sage.

Purwanti, D., Irawati, I., \& Adiwisastra, J. (2018). Efektivitas Kebijakan Penerimaan Peserta Didik Baru Sistem Zonasi Bagi Siswa Rawan Melanjutkan Pendidikan. Dinamika.

Santrock, J. W. (2010). Psikologi Pendidikan, Jakarta: Kencana Prenada Media Group.

Shafira, U. (2019). Strategi kepala sekolah dasar dalam rekrutmen siswa baru di sdn 20 banda aceh. Ar-raniry.

Sulfemi, W. B., \& Arsyad, A. (2019). Pengelolaan Manajemen Sekolah Yang Efektif Dan Unggul. Universitas Pendidikan Indonesia.

Taruna, R. (2020). Pengelolaan Rekrutmen Peserta Didik Dalam Peningkatan Animo Masyarakat di SMAN 16 Banda Aceh. Ar-raniry.

Thoha, M. (2016). Kepemimpinan dalam manajemen. Jakarta: PT Raja Grafindo Persada.

Wiyono, B. B., Kusumaningrum, D. E., Triwiyanto, T., Sumarsono, R. B., Valdez, A. V., \& Gunawan, I. (2019). The Comparative Analysis of Using Communication Technology and Direct Techniques in Building School Public Relation. 2019 5th International Conference on Education and Technology (ICET), 81-86.

Yulianto, A. (2016). Pendidikan Ramah Anak: Studi Kasus SDIT Nur Hidayah Surakarta. 1(1), 1-20.

Yusutria, M. A. (2017). Profesionalisme guru dalam meningkatkan kualitas sumber daya manusia. Curricula: Journal of Teaching and Learning, 2(1). 